Article

\title{
Transition of Collective Land in Modernistic Residential Settings in New Belgrade, Serbia
}

\author{
Milica P. Milojević *, Marija Maruna® and Aleksandra Djordjević(i) \\ Faculty of Architecture, University of Belgrade, 11000 Belgrade, Serbia; marija.maruna@arh.bg.ac.rs (M.M.); \\ aleksandra.dj@arh.bg.ac.rs (A.D.) \\ * Correspondence: m.milojevic@arh.bg.ac.rs
}

Received: 30 September 2019; Accepted: 15 November 2019; Published: 16 November 2019

\begin{abstract}
Turbulent periods of transition from socialism to neoliberal capitalism, which have affected the relationships between holders of power and governing structures in Serbia, have left a lasting impact on the urban spaces of Belgrade's cityscape. The typical assumption is that the transformation of the urban form in the post-socialist transition is induced by planning interventions which serve to legitimize these neoliberal aspirations. The methodological approach of this paper is broadly structured as a chronological case analysis at three levels: the identification of three basic periods of institutional change, historical analysis of the urban policies that permitted transformation of the subject area, and morphogenesis of the selected site alongside the Sava River in New Belgrade. Neoliberal aspirations are traced through the moments of destruction and moments of creation as locally specific manifestations of neoliberal mechanisms observable through the urban form. Comparison of all three levels of the study traces how planning and political decisions have affected strategic directions of development and, consequently, the dynamics and spatial logic of how new structures have invaded the street frontage. The paper demonstrates that planning interventions in the post-socialist transition period, guided by the neoliberal mechanisms, has had a profound impact on the super-block morphology.
\end{abstract}

Keywords: post-socialist transition; land-use; public space; urban-form; Serbia; collective land

\section{Introduction}

\subsection{Theoretical Framework}

Understanding neoliberal aspirations in the morphogenesis at the street level requires knowledge about the relationships and interdependence between socio-political changes and urban policies. Accordingly, a study of the path-dependent, contextually specific interactions between inherited restructuring projects over a broad range of geographical scales is needed [1]. The main street in the modernistic setting can be observed as a specific urban landscape and, as such, can serve as a case study which builds on the previous knowledge that identified and elaborated the changes of the urban landscape in relation to significant political changes [2-6]. In recent years, a number of scholars have researched and embraced the ways in which post-socialist cities have changed, as observed dominantly through urban geography, urban sociology, economics, and regulations, while research in the domain of urban morphology has remained underdeveloped, concerning both specific urban form studies and studies developed as a part of interdisciplinary research. Conzen's broad explanatory work took into account the morphogenesis and a morphogenetic method as a means to follow the urban landscape, regarding the historical and geographical development of the specific area, but has rarely been interlinked with planning practices, despite the importance of the physical structure of the urban areas being planned [7]. 
Guided by neoliberal influences, urban planning stems from policies that primarily advocate the principles of efficiency and economic growth. This, consequently, influences the design solutions conditioned by the market that favor profitable investments and foster competitive development [8]. The outcome of these strategies is an unequal distribution of spatial resources, accompanied by the exclusion and segregation of economically deprived citizens $[9,10]$. In these circumstances, public planning comes to the aid of neoliberal aspirations by guaranteeing private investments and reducing uncertainty; which is mainly reduced to zoning and land-use plans. Just like service provision in the public sector, urban development is mainly given over to private operators. Consequently, landowners seek to maximize the value of their land through development [11]. McGlynn argues for the so-called powergram structure, in which the power that various stakeholders have over the built environment highly depends on the political and economic systems which they operate [12].

Focusing research into current neoliberal practices at the city level requires exploration of the contextual embeddedness of city transformations in the national framework, as defined by the legacies of the institutional framework, policy regimes, regulatory practices, and political struggles $[1,9,13]$. The impact of the contemporary processes of neoliberalization on cities can be viewed through the transformation of the urban environment. The urban environment is constituted by urban form, public space, and infrastructure, and can be observed as a collective endeavor influenced and shaped by a diversity of stakeholders [14]. Planning plays a critical role here, as it reflects the objectives of the dominant market logic [9]. This is apparent through the mechanisms of neoliberal localization which, as identified by Brenner and Theodore, include, on one hand, moments of destruction: (1) The elimination and/or intensified surveillance of urban public spaces; (2) the destruction of traditional working-class neighborhoods in order to make way for speculative redevelopment; and (3) retreat from community-oriented planning initiatives. On the other hand, there are moments of creation: (A) The creation of new privatized spaces for elite/corporate consumption; (B) the construction of large-scale megaprojects intended to attract corporate investment and reconfigure local land-use patterns; and (C) the 'rolling forward' of the gentrification frontier and the intensification of socio-spatial polarization [1].

Transition processes in post-socialist countries share many hallmarks, including the democratization of politics, a return to the principles of a market economy, commercialization, privatization, the disappearance of the welfare state, fiscal crises, inflows of foreign capital, changes to the value system, and so on $[15,16]$. Key checks and balances established by post-socialist nations in response to transition processes entail, first and foremost, de-centralization of the governance system and a shift of responsibility for decision-making to the local level, with the simultaneous creation of regulatory mechanisms to control the actions of new stakeholders on behalf of the public interest [17].

This order makes new demands on urban planning, such as efficiency, flexibility, and responsiveness $[15,18]$, tilting the balance from the once-paramount position of the state in creating urban policies to the favor of developers, who are now able to dictate the avenues and means of development. Nevertheless, financial constraints mean that capital interests are afforded priority, which, in turn, transforms the traditional role of urban planning from an instrument of the state, serving to protect the public interest, into a local development mechanism, subservient to the interests of developers. Land ownership is particularly affected by these alterations in that privatization benefits capital, reducing the state's ability to act to safeguard the public interest and constraining the scope of action $[15,19]$. Consequently, changes to land ownership have a direct bearing on shifts in the planning approach [20,21].

These are the main reasons why this research has been conceptualized, to enable systematization of the change of the urban form in relation to the neoliberal mechanisms in the specific case of a modernistic setting.

The impact of neoliberal aspirations on the morphogenesis of Jurija Gagarina ('Yuri Gagarin') Street was investigated using a chronological case study research strategy. This method proved appropriate for this type of research, as it is aimed at describing the features, context, and processes of a complex phenomenon. The key research methods employed for the case study were a review 
of publicly available archival records (i.e., plans and amendments) and secondary sources regarding urban planning in Belgrade.

\subsection{Context}

Turbulent periods of transition from socialism to neoliberal capitalism, which have affected the relationships between the holders of power and governing structures in Serbia, have left a lasting impact on urban spaces. This is most evident in the transformation of the urban form. Land-use planning has been identified as an efficient instrument for implementing the public policy value framework [22]. Additionally, research performed to date into urban policies in Serbia's post-socialist transition period has looked at the totality of the planning system, but not at the role of its particular aspects, such as planning interventions.

Belgrade provides a good example for an analysis of these transformations, both due to the massive centralization of the economic (and other) activity and power over the past 20 years-which has made the city particularly attractive within Serbia-and its interplay between the various stakeholders and interest groups [21,23-27]. Economic liberalization became a reality as early as the start of the 1950s, when the concept of worker self-management was first introduced. Flows of Western ideas were made visible in the architectural space of Belgrade, especially in the case of the new communities which anticipated the general progress of the economy and society, symbolizing the power of the state and the openness of the country. The best illustration of this approach can be found in New Belgrade, where local ideological and economic challenges have been merged with international flows [28].

Moreover, socialist urban development perceivable through the modernistic setting and post-socialist transition are well-placed to serve as a testing ground for demonstrating value system changes. Additionally, in the existing body of knowledge, little attention has been given to urban design, especially the public space of the modernist cityscape [29] and ordinary social housing and the townscape, when compared to individual, iconic buildings [30].

A particular feature of the morphology of New Belgrade is the so-called 'super-block', an open-plan urban form characterized by a developed infrastructure, easy access to transportation, and public ownership of land. These characteristics are reasons why the New Belgrade blocks became attractive venues for construction at the time of transition [19]. Under-utilization and problems with maintaining open spaces were the main arguments put forward by city authorities in justifying the sale of urban development land zoned for public use and to promote intensive construction in New Belgrade. New structures, primarily constructed directly abutting the build-to line, have drastically altered the open character of these blocks and the New Belgrade cityscape.

We focused our research on the morphology of the street, in relation to the open block, as it is believed that urban planning can regulate the urban form of the cityscape by prescribing rules about the setback, floor, and built-up area ratio, building heights, front continuity, ground floor usage, and public space. As has been noted by Talen, street frontage is what defines the public realm and, as such, it has acquired great interest throughout the planning history since it is essential for distinguishing public from private responsibilities [31].

More broadly, this paper is aimed at revealing how and when planning decisions (amendments to plans) have shaped the dynamics and spatial logic of the creation of a new urban form. In a narrower sense, the research was intended to shed greater light on the nature of planning interventions during post-socialist transitions, as observable through alterations to the strategic directions of development that are the preconditions for the creation of urban forms. The starting assumption is that planning interventions in the post-socialist transition have been induced by neoliberal aspirations originating from the Yugoslav socialist period. This hypothesis is based on the view that neoliberalism mobilizes the urban space as an arena for market-oriented economic growth and elite consumption practices and, in doing so, it transforms the political-economic setting in which public plans and projects are implemented [9]. Established circles of power can exert a decisive influence on setting land-use priorities [32-34]; as such, the objective of this study is to explore the urban landscape, reflecting the 
aspirations of the dominant powers in society. Keeping in mind Soaita and Dewilde's elaboration [6] that the post-socialist cities of Eastern Europe have been exposed to the challenges of transition in various manners, we discuss how the neoliberal mechanisms have influenced urban planning and design in Serbia, following the end of the Yugoslav socialist self-government.

\section{Materials and Methods}

\subsection{Methodological Approach}

The methodological approach was broadly structured as a chronological case analysis at three levels. The first level entails identification of the particular historical periods that set the stage for urban policy-making, while the second level comprises an analysis of planning policies, namely those that enabled spatial changes in the subject area. The third level provides insight into the specific changes in space (land ownership, land-use, built and unbuilt land ratio, and changes in scale and dimension of the area affected by the new construction/development areas). The main focus of the paper is identifying the relationship between amendments to planning documents and identifying changes in the urban form (Figure 1).

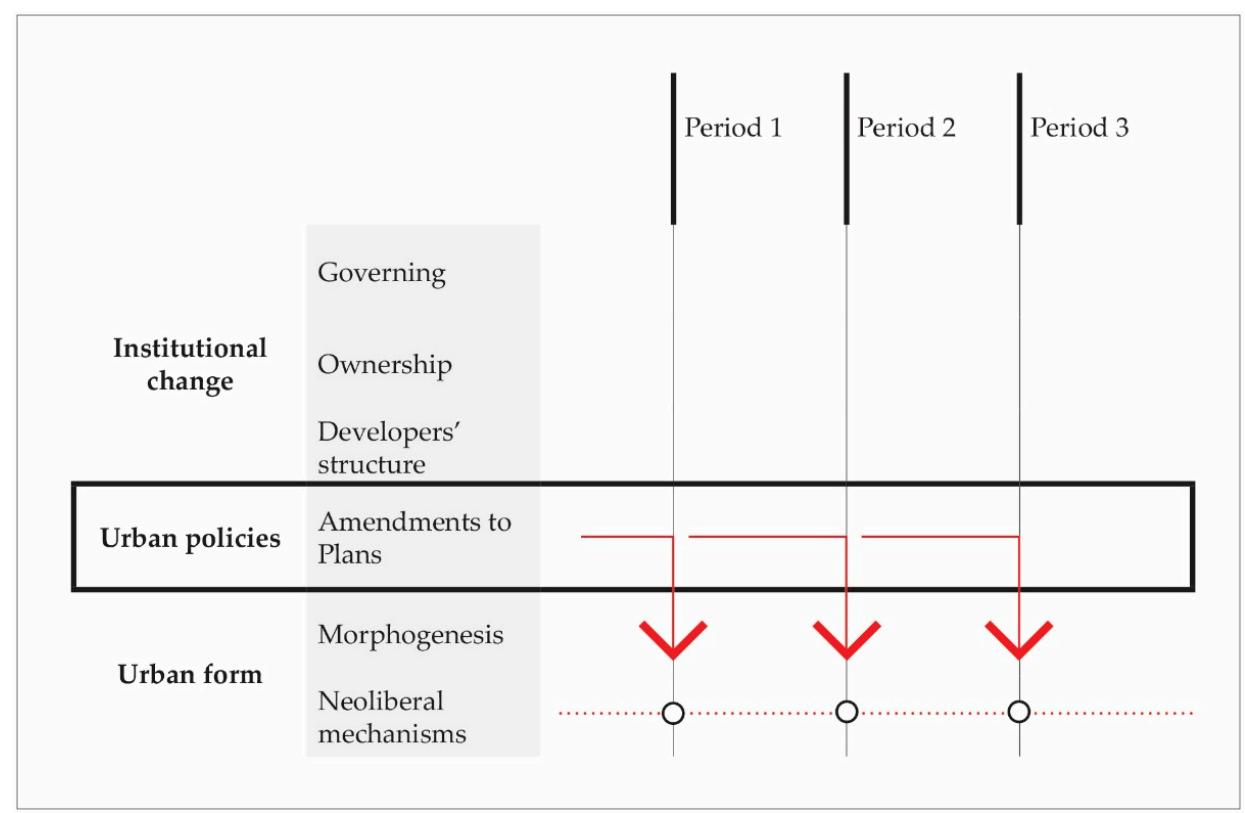

Figure 1. Methodological approach: Chronological case analysis at three levels.

The first level examines institutional changes related to the domains of governance, land ownership, and developer structures. The research is focused on monitoring the institutional changes which have benefited the capital. This first level mainly relies on secondary sources, which present the critical interpretations of changes to the Serbian planning system used to identify main historical periods.

The second level attempts to understand changes to the patterns of planning intervention, including historical analysis of the urban policies that permitted the transformation of the observed location. These changes are most visible on Jurija Gagarina Street, the principal thoroughfare and developmental backbone of the neighborhoods along the Sava River, which was selected as a research polygon. The analysis here looks at the planning documents produced over the three historical periods; both at the macro level, where general urban plans define the broader strategic directions of spatial development, and the micro level, where urban policies of the observed segment of the urban structure are more elaborate, using general regulation plans and detailed regulation plans. This level of research is based on data from planning documents obtained from the Central planning register and historical plans obtained from the archives of the Urban Planning Institute of Belgrade (see Table 1). Special 
attention has been paid to the amendments which enabled spatial changes to occur in the later stages of the morphogenesis of the subject area. Additionally, these plans provide a textual and graphic ground to form a selection of data on land-use, regulation parameters, and land ownership status.

Table 1. The size of consequences, as determined by each planning system (Source: authors).

\begin{tabular}{|c|c|c|c|c|}
\hline & & & Period 2 & \\
\hline & & $\begin{array}{c}\text { Period } 1 \\
\text { The end of Socialist } \\
\text { self-management period }\end{array}$ & $\begin{array}{l}\text { The break-up of } \\
\text { Yugoslavia and } \\
\text { collapse of the } \\
\text { socialist system }\end{array}$ & $\begin{array}{l}\text { Period } 3 \\
\text { The period of } \\
\text { transition }\end{array}$ \\
\hline $\begin{array}{c}\text { Urban } \\
\text { policies }\end{array}$ & $\begin{array}{l}\text { Planning } \\
\text { dicuments } \\
\text { amendments }\end{array}$ & $\begin{array}{c}\text { Amendments to the } \\
\text { General Master Plan for } \\
\text { Belgrade (1985) } \\
\text { Detailed Urban Plan and } \\
\text { Urban design project for } \\
\text { Block } 44 \text { (1982) } \\
\text { Amendments to Detailed } \\
\text { Urban Plan for Block } 44 \\
\text { (1985) }\end{array}$ & $\begin{array}{l}\text { Amendments to } \\
\text { the Detailed Urban } \\
\text { Plan for the area of } \\
\text { Bežanija (1992) } \\
\text { Amendments to } \\
\text { the DUP for Blocks } \\
45 \text { and } 70 \text { (1992) }\end{array}$ & $\begin{array}{c}\text { Amendments to the } \\
\text { General Master Plan } \\
\text { for Belgrade (2003) } \\
\text { Amendments to the } \\
\text { General Master Plan } \\
\text { for Belgrade (2009) } \\
\text { The General } \\
\text { Regulation Plan (2016) }\end{array}$ \\
\hline \multirow{4}{*}{$\begin{array}{l}\text { Urban } \\
\text { form }\end{array}$} & Land-use* & $\begin{array}{c}\text { housing } 27 \% \\
\text { commercial } 42 \% \\
\text { other } 31 \%\end{array}$ & $\begin{array}{c}\text { housing } 9 \% \\
\text { commercial } 21 \% \\
\text { other } 70 \%\end{array}$ & $\begin{array}{c}\text { housing } 36 \% \\
\text { commercial } 64 \% \\
\text { other } 0 \%\end{array}$ \\
\hline & Built-unbuilt area & $1: 10$ & $1: 7$ & $1: 5$ \\
\hline & Land ownership & $\begin{array}{l}\text { (state : dwelling } \\
\text { community) 1:1.52 }\end{array}$ & $\begin{array}{c}\text { (public : other) } \\
\text { 1:0.5 }\end{array}$ & $\begin{array}{c}\text { (public : private) } \\
1: 0.2\end{array}$ \\
\hline & $\begin{array}{c}\text { Development } \\
\text { area [ha] } \\
\text { (area affected by } \\
\text { new } \\
\text { construction) }\end{array}$ & 38.33 & 19.2 & 12.3 \\
\hline
\end{tabular}

The third level presents the morphogenesis of the frontage along Jurija Gagarina Street, analyzed through the three stages of transformation of the super-block, an initial morphological unit of New Belgrade. Neoliberal influences are traced through the analysis of character areas of modernistic residential settings, identified as a combination of the ground plan, building form, and land-use that have undergone significant changes over time. The very components of urban areas and used terminology have been identified and broadly researched by Conzen [35]. It ought to be noted that the space of the street was viewed as an urban unit that (1) combines the characteristics of a built structure that constitutes the street frontage with its appropriate open spaces; and (2) includes zoned land for development as an integral element of the street frontage, rather than merely a public space between buildings.

This research level implied the development of a digital database and the integration of analog data from detailed regulation plans with the digital cadastral base of the Republic Geodetic Authority to observe and compare physical changes throughout all three periods of the area's development. Data on the changes before 2001 in urban form were developed according to the official electronic real estate cadaster of the Republic Geodetic Authority, while the data from 2001 to the present day were monitored based on orthophoto imagery (Google Earth, Belgrade, Serbia) and field observations. AutoCAD tools were used to develop individual maps and to generate numerical data (land area).

The scope of detailed regulation plans was used to determine the boundaries of the development area during each period. At the same time, the plot size and building parameters of each constructed unit were used to identify the morphological unit perceived as a development pattern.

Finally, a multi-criteria comparison analysis was made based on the criteria of (1) land ownership, (2) land-use plan, (3) built/unbuilt area, and (4) development area. Based on these, changes in the 
urban form were expressed; both graphically and numerically. The spatial change dynamics were monitored through the relationships of the following:

1. Changes in land ownership: public and other land;

2. Changes in dominant land uses: housing and commercial activities;

3. Changes in floor area ratio: built and unbuilt surfaces; and

4. Changes in the morphological unit: development area.

Changes were expressed in terms of parameters, while physical transformations were presented both graphically and numerically to understand the intensity of the changes described. Urban morphology and morphological research, in general, may provide insights on how to plan and manage the urban growth and regeneration that are still insufficiently clear and investigated, as suggested by Kropf [11]. In this respect, description of the identified changes in the urban form has been systematized according to the matrix of the moments of destruction and moments of creation [1], which enable the identification of locally specific manifestations of neoliberal mechanisms in Belgrade, and allow us to compare them to the experiences of other cities.

We consider that it is important for research to highlight the inevitability of new structures occurring, as well as to open up a discussion on how these changes affect the regeneration of settlements and public spaces of the open block.

\subsection{Case Study Area}

The subject area was a $2.3 \mathrm{~km}$ long segment of the central street in the residential complex in New Belgrade. The north side of the street is enclosed by blocks 61-64, while the south side is enclosed by blocks 44,45 , and 70 . The analysis covers an area of 145 ha (Figure 2). This district was initially constructed to house 90,000 residents and was set up in a line of super-blocks.
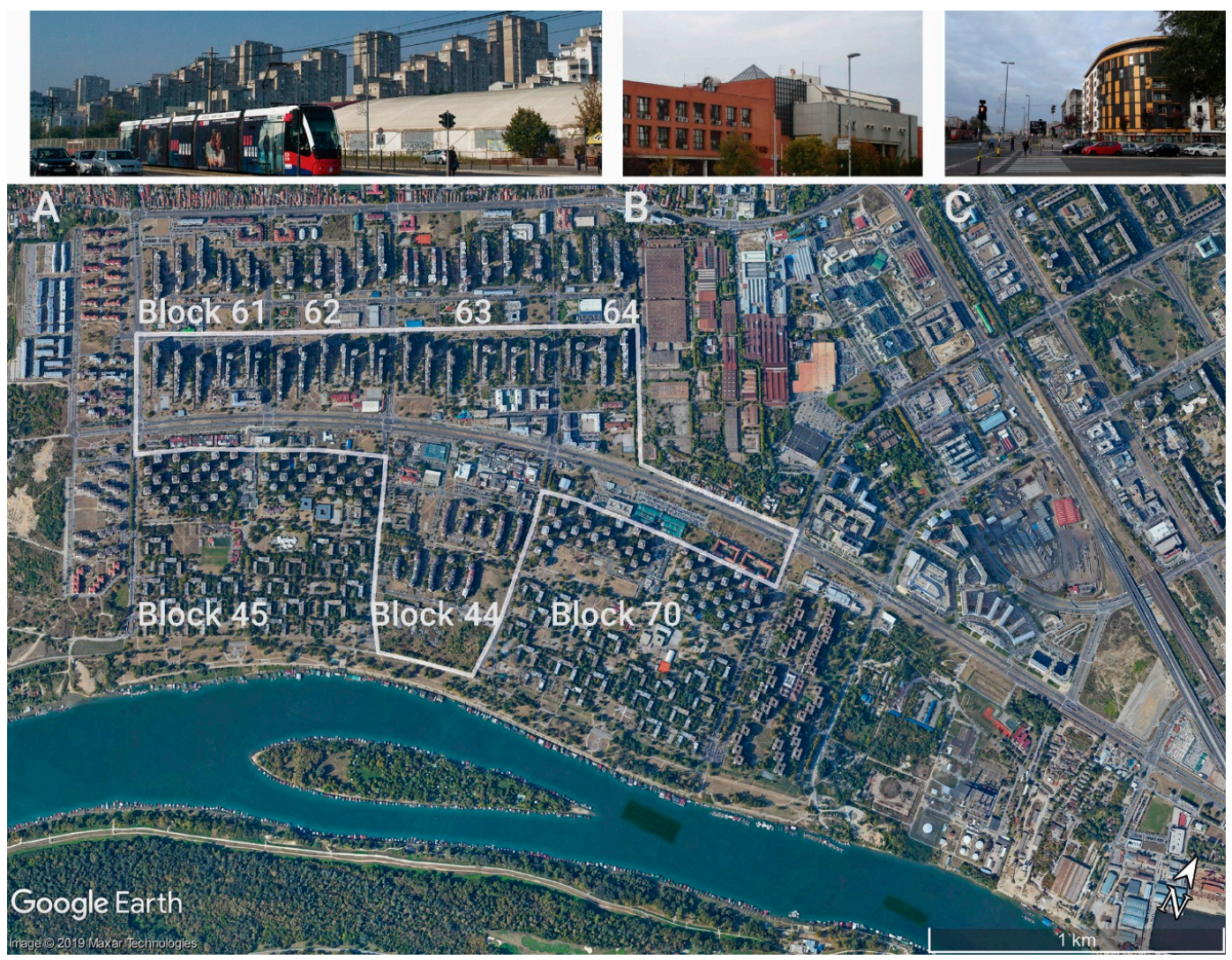

Figure 2. Case study area: Jurija Gagarina Street (Source: Google Earth, October 2019; Photos by the authors). 
Settlements and individual buildings in blocks $45,61-64$, and 70 are well-known as a representative example of Brutalist architecture and mass-housing construction in the 1970s, especially among the architects and researchers of modernism in Yugoslavia (Figure 2A). Block 44 occupies the central segment of the subject area and, at the same time, presents the initial spot where the transformation of this settlement begun and where the first deviation from the original plan occurred. The construction of this part of the settlement marked the end of a period of socialist self-management, and has not been elaborated in detail. Elements of blocks 45 and 70 stand out as separate entities in the settlement, where the first shopping malls were formed during the economic crisis (Figure 2B). In the last two decades, new construction has taken place on the narrow street area along blocks 61,63 , and 64 oriented towards the street (Figure 2C). It is essential to consider the magnitude of these changes and their origin, as not only has the character of the street changed, but the open block has been transformed from the initial development pattern and overall landscape of the settlement.

\section{Results}

The case study was structured as a chronological analysis at three levels: Identification of the three basic periods of institutional change, followed through the contextual framework and historical analysis of the urban policies that permitted the transformation of the selected narrow street area and morphogenesis of the selected site alongside the Sava River in New Belgrade. The three basic periods are structured as (1) the self-management period, (2) the break-up of Yugoslavia and collapse of the socialist system, and (3) the period of transition. These periods were taken as a contextual framework concerning the genesis of the street and observation of the open block.

\subsection{Contextual Framework}

\subsubsection{Socialist Self-Management Period}

After World War II, a socialist governmental system was established in Yugoslavia. This broke the legal continuity of the former Kingdom of Yugoslavia, thus introducing a centralized planned economy and a social system based on the dominance of collective interests, with state ownership of land in urban areas [36]. Worker self-management was introduced after 1953, and institutions were de-centralized. The adoption of the 1963 Constitution of the Socialist Federal Republic of Yugoslavia continued the de-centralization trend of the governance system through the so-called 'socio-political communities', local authorities responsible for social and economic development issues. These reforms also led to the emergence of market socialism $[19,36]$, creating a state where all decisions about development were made by political nomenclatures at the central level and then imposed on local communities.

A specific type of self-management was introduced in the 1974 Constitution, which familiarized the notions of 'associated labor', 'consensus economy', 'self-management agreements', 'social compacts', and de-centralized decision-making [19]. This institutional transformation, which took on the name of 'social planning', promoted local self-governance and self-management institutions whilst leaving the Federal level only with a residual role in enacting and harmonizing core policies [37]. In line with these trends, urban planning became more flexible and separate from other policies; at the same time promoting a bottom-up approach in urban policy-making [19]. Constitutional amendments were accompanied by the enactment of numerous town- and regional-level Planning Acts that treated planning subject matter and practice very thoroughly in the conceptual and technical perspectives, accompanied by guides and manuals. This period has been considered the 'golden age' of Serbian planning [36].

\subsubsection{The Break-Up of Yugoslavia and the Collapse of the Socialist System}

In the late 1980s, under the influence of international institutions, socialist nations throughout Europe embarked on market reforms founded upon the imperatives of neoliberalism [19]. This period was marked by the emergence of the private sector and private entrepreneurship, a trend that was 
particularly pronounced in the construction industry, resulting in numerous so-called 'construction laws' that benefited private developers. Later on, in the 1990s, private ownership of development land was permitted for the first time after World War II [19].

Nevertheless, the transition of the socio-economic system in socialist Yugoslavia was interrupted in the 1990s by the disintegration of the federal state and civil wars. The break-up of the country was compounded by an absence of economic and social reforms and the inability of the political elite to transform the system [36]. Finally, Serbia was placed under international sanctions, which dramatically reduced its living standards. Faced with these challenges, the state strongly centralized its institutions, abolished the principles of self-management, and removed powers and finance from the hands of local authorities. Serbia's economy was devastated; the country was torn from within, internationally isolated, and shattered by war, with no clear strategic policy [19]. In consequence, urban development took place in an environment characterized by weak and inadequate institutions, an undefined regulatory framework, and unclear procedures, leading to mass abuse and uncontrolled construction. It ought to be noted that this period was marked by mass privatization of socially owned housing units throughout Serbia, which brought personal and private interests to the fore with all planning and governance stakeholders.

\subsubsection{The Period of Transition}

Since 2000, transition in Serbia has been characterized by the establishment of formal structures of democratic governance, at both the central and local levels, accompanied by governmental de-centralization. A major change in spatial and urban planning occurred in 2003 with the enactment of the Planning and Construction Law, which made it easier for local governments to dispose of land, whilst the 2006 Constitution allowed the private ownership of development land. These regulatory reforms were fully put into effect only with the adoption of the 2009 Planning and Construction Law, which introduced mechanisms for the privatization of land and transactions involving land plots. Frequent changes to building laws were primarily aimed at attracting investment and, thus, permitting more efficient construction. This led to simplification of the planning system and a greater flexibility in the planning process. However, despite the introduction of a multitude of planning instruments (e.g., retrospective planning permission, accountability of professional planners and builders, and central-level spatial planning agencies), numerous problems have remained unsolved, with unpermitted construction remaining the most significant issue. Above all, the legitimacy of the plurality of interests and partial sources of finance has not been recognized as being fundamental to spatial development $[38,39]$. Moreover, the public was not given a substantive say in the planning process. The procedure envisaged citizen participation at the very end of the planning process exercise, but authorities were under no obligation to adopt any objections made to plans.

Other regulatory changes have been made in recent years, which have altered the planning paradigm towards a greater recognition of collaborative and communicative planning considerations. First of all, strategic planning has received legitimacy as the basis for public policymaking; national strategic priorities now reflect sustainable development principles; institutions are required to collaborate, both horizontally and vertically, in spatial development; and the institutionalization of public-private partnerships has been proposed $[40,41]$.

\subsection{Urban Policies}

\subsubsection{Socialist Self-Management Period: Housing Construction as the Priority}

The time between 1945 and 1982 was the period in which Belgrade was planned, designed, and built, according to the urbanist standards and values suited to a European metropolis. By the late 1960s, it had become apparent that the population of Belgrade, the administrative center and capital of the Socialist Federal Republic of Yugoslavia, would exceed one million. These considerations prompted the amendment of the 1950 General Master Plan (GMP), leading to the enactment, in 1972, of the GMP 
for Belgrade to 2000. From a methodological standpoint, this plan has been considered the pinnacle of Yugoslav planning practice. This period came to an end with the first deviations from the plan in the mid-1980s. An assessment of the mismatch between the actual development and the 1972 plan led to the enactment of more feasible planning solutions. The amendments to the GMP adopted in 1985 signaled the demise of self-management urbanism.

In the Belgrade GMP to 2000, Jurija Gagarina Street was designated as the key thoroughfare for the residential blocks along the Sava Riverfront of New Belgrade, along with central features which were to be planned [42]. The scope of the Detailed Urban Plans (DUP) was based on the idea to create unique spatial and character areas, ranging from 115 ha in blocks 45 and 70-165 ha in blocks 61-64. The beginning of the fragmentation of the morphology of the superblock in the planning documents was induced by amendments to the GMP [43] by the DUP and the urban design project (UD) for Block 44 [44], which covered only 36 ha of the site. Substantial changes dealt with the land-use of New Belgrade's Block 44, in which a site intended as a district center and sports and recreation facility was re-zoned for primarily residential use. Amendments to the Block 44 DUP [45] increased the residential and commercial capacity of the site, while the initially planned sports and cultural areas have remained unbuilt, to date. In this way, the morphological unit was reduced from an open-plan block to a group of modular morphological units. A change of area character-perceived as a combination of ground plan, building form, and land utilization - became evident in the narrow street area, due to the construction of three-story commercial buildings in front of residential towers. Detailed Urban Plans for the parts of Blocks 45 and 70 abutting Jurija Gagarina Street were not implemented at this time [46].

3.2.2. The Break-Up of Yugoslavia and Collapse of the Socialist System: Legitimization of Private and Individual Interests

The period from 1992 to 2000 was marked by unplanned construction on a vast scale and the allocation of sites throughout the city to certain 'successful' developers. This practice began as the federal state collapsed and international sanctions were imposed.

During this period, Jurija Gagarina Street was the venue for two parallel processes; namely, both the planned and the unplanned occupation of undeveloped plots of land. With no plan, but systematically, sites at the corners of the blocks were occupied by temporary structures (news-stands). 'Successful developers' had their interests enshrined in amendments to DUP which affected the planned use of the street for central functions. Attractive sites in Blocks 45 and 70 were allocated to ENJUB (a joint venture formed in 1989 by the major state-owned bank Jugobanka and large state-owned construction firm Energoprojekt as a limited liability company intended to build, refurbish, and sell residential and other properties).

Along the street frontage of blocks 61-64, sites for central facilities were reserved by Amendments to the DUP for the area of Bežanija (Blocks 61-63 and parts of Blocks 57, 57a, 60, and 62) in New Belgrade [47]. Amendments to the DUP for Blocks 45 and 70 allowed residential and commercial structures abutting the street to be built [48]. This permitted the first buildings of such a kind to be constructed there. The number and size of commercial and retail premises on the ground floors of residential buildings or in standalone small-scale shopping centers were suited to the rising importance of small businesses. Amendments to the DUP for Blocks 61-64 allowed parcels zoned for development to be created along street frontages; however, these remained undeveloped to the end of this period. In this period, DUPs were developed only for the super-block fragments covering the area of $11.27 \mathrm{ha}$ in block 70 and 5.41 ha in block 45. Fragments were further subdivided into plots covering an area of 0.24-2.2 ha. The fragmentation that was induced in this first period only became more intense and more evident, reaching its peak when news-stand shops were placed along the street as a manifestation of the illicit trade and the 1990s sanctions. Even though the morphological unit in the planning documents was reduced to a mixed-use plot (housing with small retail space), it was reduced to the scale of newsstands in reality, which started to group in the narrow street area, especially at the intersections of main roads. 


\subsubsection{The Period of Transition: "Unquestionable" Projects}

Belgrade lost the cachet of a metropolis following a decade of devastation. After 2000, strategic development efforts were undertaken to position Belgrade amongst European cities as a major urban center in southeastern Europe [49]. Regaining the status of a major European city and becoming competitive with metropolises along the Danube became the key objectives of the General Master Plan for Belgrade to 2021.

The political and economic security of investment was seen as a precondition for development. Apart from creating an environment suitable for capital projects, the city was faced with the social problems of a society in transition, issuance of retrospective planning permissions for structures built in the preceding period, and re-assessment of instruments for implementing the GMP and facilitating investment.

Social housing was planned at 58 sites to mitigate economic and social issues; two of these locations were on Jurija Gagarina Street, in parts of Blocks 61 and 63. According to the GMP [49], eligibility for social housing is determined by the city's policy. The GMP reviewed the land-to-building ratio of open-plan blocks and allowed densification (commercial structures were limited to 13 stories and the permitted land-to-building ratio was up to 2.2). A public planning and architectural competition was proposed for the design of Jurija Gagarina Street as an urban boulevard. It was suggested that infrastructural facilities be removed from the street in a 2003 study entitled 'Comprehensive assessment of the Jurija Gagarina Street area'.

Amendments made to the GMP in 2009 allocated Jurija Gagarina the role of a commercial and retail thoroughfare, allowing changes to the planned use of plots directly abutting the street to a depth of 40 metres [50]. The General Regulation Plan [51] mandated the direct application of the GMP to the entire observed area of Jurija Gagarina Street. This direct application required the issuance of extracts from the GMP or confirmation of the compliance of urban design with the GMP, which shortened the public inspection procedure and gave the public less say in the decision-making of expert committees. A faster permitting procedure became the priority of planning practice, whilst the origin of investment and projects remained beyond any questioning. The planning instrument for implementation of the GMP in this period was the urban design project, developed for small areas that usually did not exceed 1 ha. Plots in the narrow street area were subdivided into fragments of 0.25 ha with eight-story residential buildings, creating new character areas along the street.

\subsection{Fragmented Character of Open Block: Morphogenesis of Jurija Gagarina Street}

Three stages of transformation of the super-block can be recognized in the morphogenesis of Jurija Gagarina Street. These stages coincide with the three periods of socio-political change in Serbia. The stage before the transformation was the initial phase in the development of the modernist settlement in New Belgrade (Figure 3). Ownership of the land was collective (state or local community) (Figure 3A). Collective housing was the dominant land-use, accompanied by amenities such as nursery schools, elementary schools, local centers (e.g., administrative community centers), and sports and culture (e.g., settlement centers) (Figure 3B). The street frontages of the residential blocks took a Brutalist architectural appearance: residential towers along the southern side of the street and mega-structures on the northern side of the observed section (Figure 3C). The integration of green and built areas within the open-plan block was the dominant principle of the initial development pattern implemented in this period (Figure 3D), as the protection of the environment was an integral part of the socialist self-governmental restructuring of society [52]. 


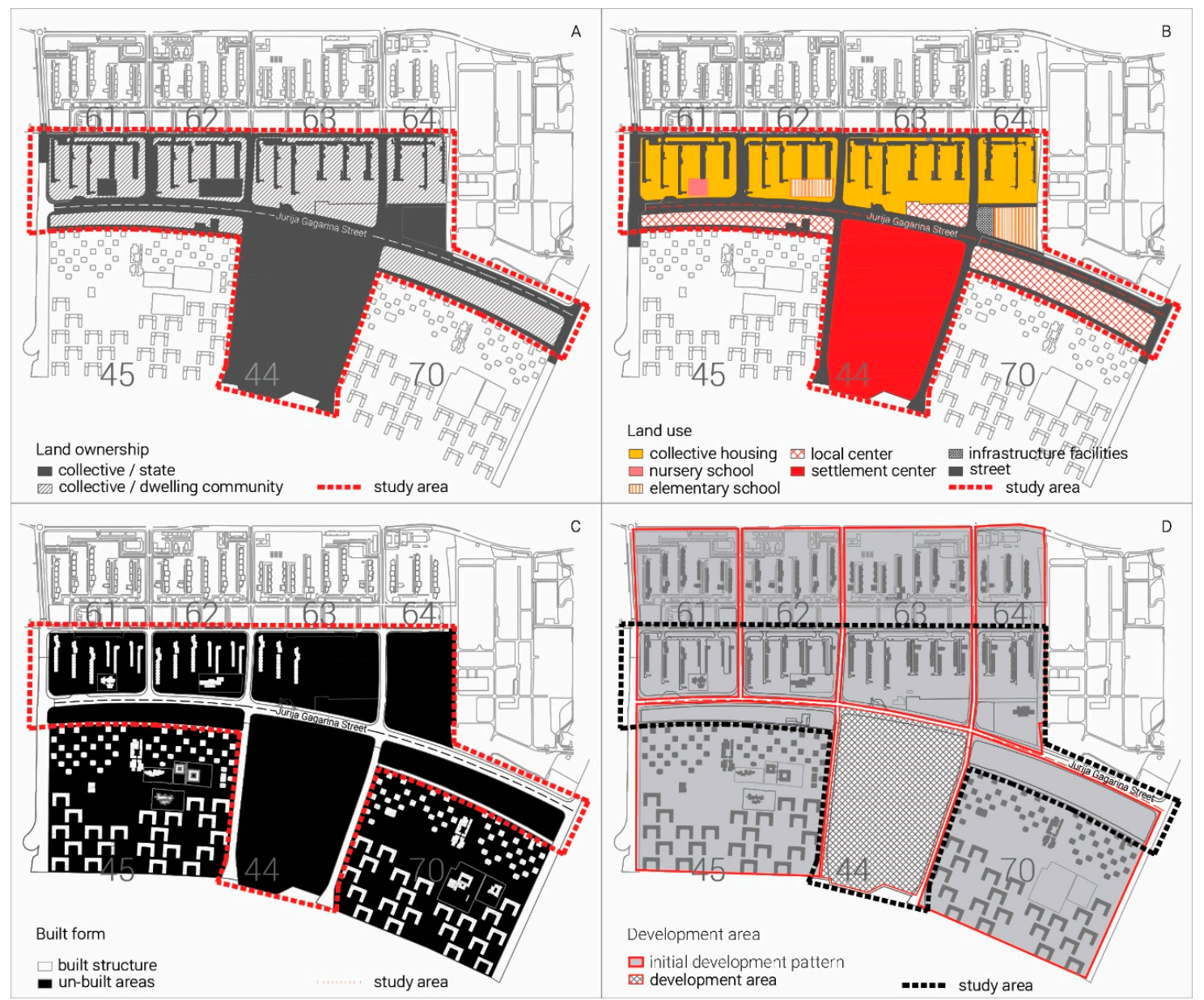

Figure 3. Morphogenesis of Jurija Gagarina Street, initial phase: (A) Land ownership, (B) land-use, (C) built form, and (D) pattern of growth (source: authors).

\subsubsection{Socialist Self-Management Period: Abandoning of the Initial Character Area}

The first stage, placed in Period 1 (Figure 4), was marked by the first change of open-plan blocks within a free, undeveloped belt abutting Jurija Gagarina Street. The new development area was recognized in the unbuilt area of block 44, where the district center had been planned. The ownership of the land remained collective (state or local community) (Figure 4A). In this period, the priority of development was housing issue and supply services: a farmer's market, a department store, and a shopping mall (block 44) (Figure 4B). The only structures built in the road frontage zone were intended for social use (a nursery school in Block 61, an elementary school in Block 62, and a commercial complex in Block 44) (Figure 4C). A section of the street frontage of Block 44 formed an exception to the initial pattern: the low-rise cubic-shaped structures occupying the frontage bore the hallmarks of postmodernism and consumerism (Figure 4D). 


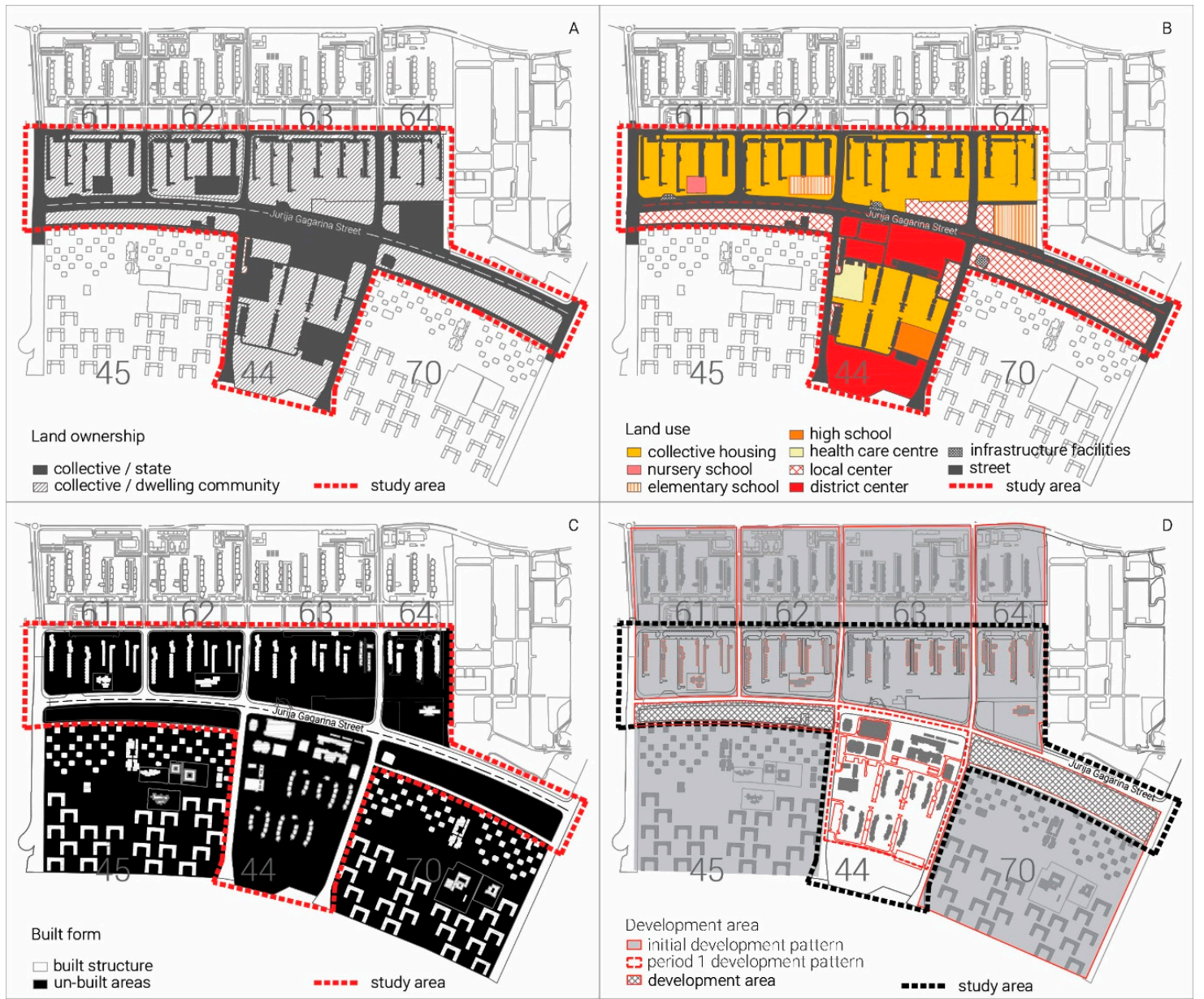

Figure 4. Morphogenesis of Jurija Gagarina Street, period 1: (A) Land ownership, (B) land-use, (C) built form, and (D) pattern of growth (source: authors).

\subsubsection{The Break-up of Yugoslavia and Collapse of the Socialist System: Division of Character Areas}

At the second stage of its morphogenesis (Figure 5), the observed section of the street witnessed the fragmentation of plots and the construction of temporary and permanent structures occupying the street frontage (Figure 5D). Ownership of the land became public or other forms of ownership (state, common, or private) (Figure 5A), while land-use was planned as a mixed-use area (multi-family housing with small businesses and services) (Figure 5B). Low-rise residential and commercial buildings were constructed in Blocks 45 and 70, while a school and a new four-story residential complex were erected in Block 64 (Figure 3C). Public spaces located at the corners of Blocks 45, 61, 62, and 70, as well as the intersections between the main thoroughfare and side streets, became occupied by informal structures. 


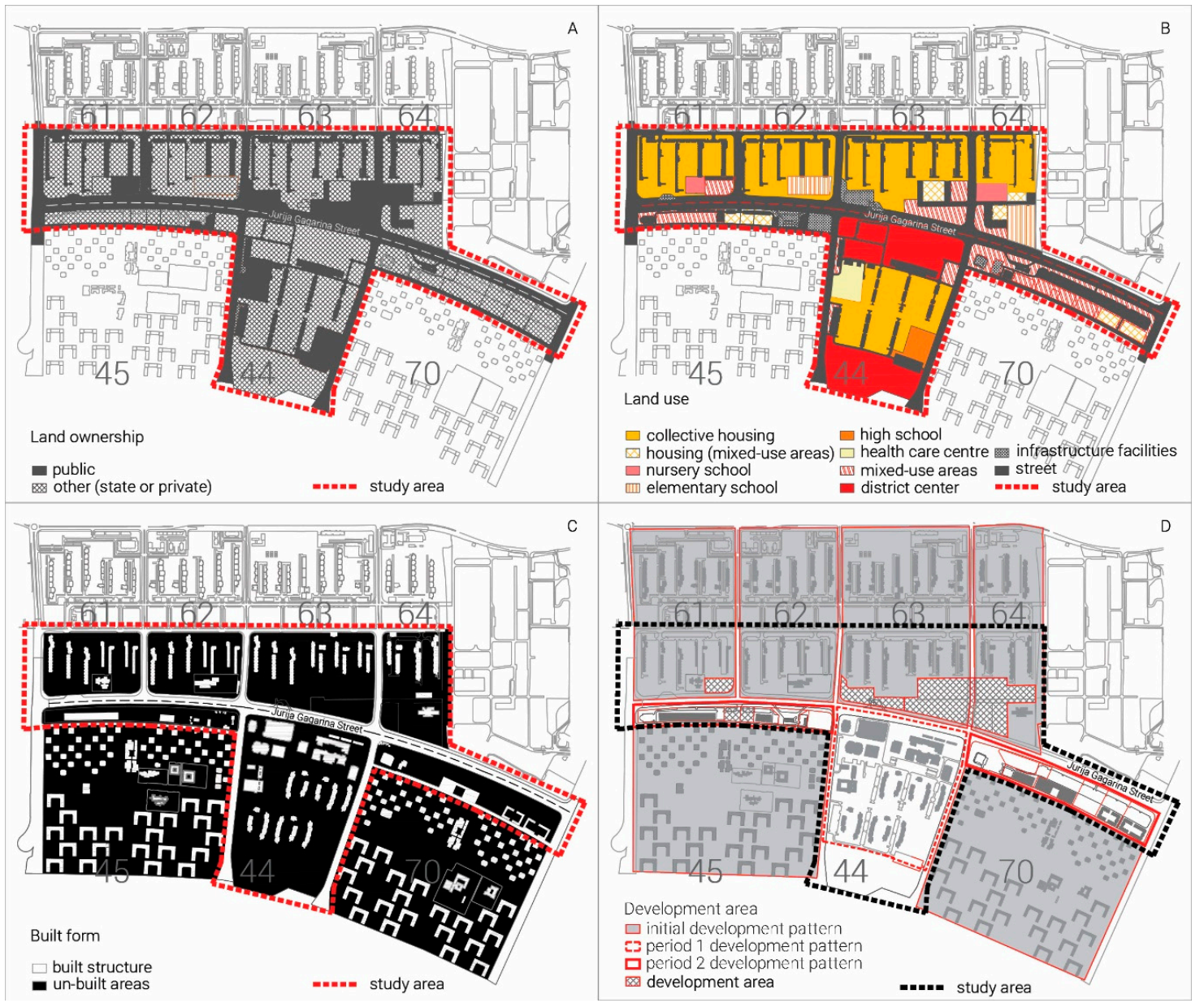

Figure 5. Morphogenesis of Jurija Gagarina Street, period 2: (A) Land ownership, (B) land-use, (C) built form, and (D) pattern of growth (source: authors).

\subsubsection{The Period of Transition: Insertion of New Character Areas}

The filling-out of the street frontage was the main characteristic of the third stage of morphogenesis (Figure 6). This process was initiated by the erection of petrol stations, followed by the construction of predominantly residential buildings on plots initially envisaged for commercial use. This period introduced two types of land ownership, divided into public or private (Figure 6A). In this period, alienation of the public land was executed in favor of private investment in the housing market. Land-use was planned as a mixed-use area with a dominant percentage of commercial facilities, while the investments changed the ratio between housing and commercial functions in favor of multi-family housing (Figure 6B). The enclosure of plots and the erection of six- and nine-story buildings in dense rows altered both the character of the open-plan block and that of the street (Figure 6C). Instead of a commercial road, this main thoroughfare of a residential area became occupied by structures dictated by the market. The transformation of the super-block in this period introduced the third pattern of growth - the plot—-with structures erected along the build-to line and the maximum land-to-building ratio (Figure $6 \mathrm{D}$ ). 


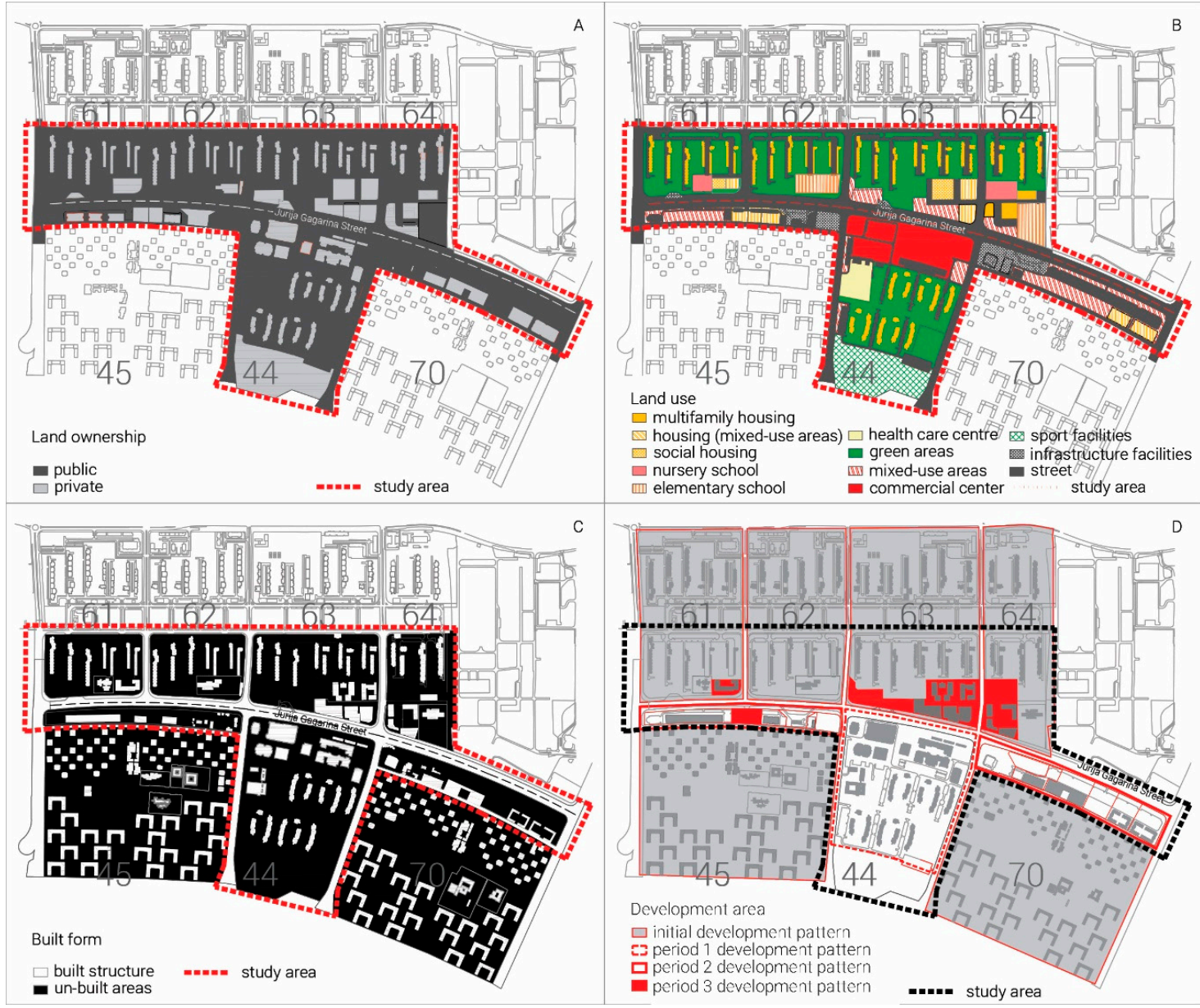

Figure 6. Morphogenesis of Jurija Gagarina Street, period 3: (A) Land ownership, (B) land-use, (C) built form, and (D) pattern of growth (source: authors).

\subsection{Dynamics and Consequences}

The change of land-use was observed through the relationship between different land-uses (see Table 1): housing, commercial (central activities), and other additional uses (e.g., traffic, greenery, and social infrastructure). In the first period, a balanced relationship between these uses can be noticed. In the second period, additional uses became dominant. In the third period, additional uses were entirely out of favor, with residential and commercial contents dominating.

The ratio change between built and unbuilt land was observed through the scope of the subject area without taking into account the area covered by streets. It can be noticed that unbuilt land decreased gradually over periods in the wake of newly built structures (Table 1). This land densification was mainly concentrated on the street frontage; while, in the third period, the block corners were occupied.

As for the change of the land ownership status (Table 1); in the first phase, there was an almost identical percentage of land owned by the state and land owned by the dwelling community. In the second stage, the land that was previously owned by the community took a public (or other) status, thus producing a state where, besides state ownership, public and collective ownership were introduced. In the third stage, private land ownership was introduced, mainly for the most attractive locations, such as the street frontage and block corners.

The change of area affected by new construction reveals that the construction area decreased (Table 1). The scope of planned construction was twice as small in the first phase when compared to the second, and three times lower if the first and third phases are compared. This can be explained by the structure of the developers. The developer structures changed from the state as a leading developer 
in the first phase, to joint ventures of state-owned firms in the second phase and, finally, to private capital in the third phase.

\subsection{Identification of Neoliberal Mechanisms in the Transformation of Fragments of Jurija Gagarina Street}

This part of the study provides a detailed overview of the neoliberal aspirations observable in the urban form of the observed fragment of the street, traced through the moments of destruction and moments of creation, as defined by Brenner and Theodore [1]. This analysis enabled visualization and understanding of what was destructed (what disappeared and what was abandoned) and what was created (new patterns) in the three different stages of development (see Table 2A,B). The structural data and analysis interpretation not only allows us to acquire insight into the state of the analyzed urban form, but also provides a platform for understanding the morphogenesis of the site.

Table 2. (A) Moments of destruction (source: authors). (B) Moments of creation (source: authors).

\begin{tabular}{|c|c|c|c|}
\hline \multicolumn{4}{|l|}{ (A) } \\
\hline $\begin{array}{l}\text { MOMENTS OF } \\
\text { DESTRUCTION }\end{array}$ & STAGE ONE (Figure 1) & STAGE TWO (Figure 2) & $\begin{array}{l}\text { STAGE THREE } \\
\text { (Figure 3) }\end{array}$ \\
\hline $\begin{array}{l}\text { Elimination and/or } \\
\text { intensified surveillance } \\
\text { of urban public spaces }\end{array}$ & $\begin{array}{l}\text { Large-scale unbuilt } \\
\text { plots. Plans to build } \\
\text { services and central } \\
\text { facilities are abandoned } \\
\text { while narrow street areas } \\
\text { remain mainly } \\
\text { underdeveloped and are } \\
\text { used as public space } \\
\text { between the street and } \\
\text { buildings. The only } \\
\text { physical structures built } \\
\text { in the narrow street area } \\
\text { are educational (blocks } \\
61 \text { and } 62 \text { ) and } \\
\text { commercial facilities } \\
\text { (block 44). }\end{array}$ & $\begin{array}{l}\text { Frontage and public } \\
\text { space subdivided. } \\
\text { Occupation of unused } \\
\text { surfaces in narrow street } \\
\text { area increases (blocks } \\
45 \text { and } 70 \text { ) and affects the } \\
\text { use of open space, which } \\
\text { becomes common, used } \\
\text { for parking spaces and } \\
\text { access roads to newly } \\
\text { built housing facilities. } \\
\text { The reduction of public } \\
\text { space at intersections } \\
\text { appears due to the illicit } \\
\text { trade (block } 45,62, \\
\text { and } 70 \text { ). }\end{array}$ & $\begin{array}{l}\text { Fragmentation of the } \\
\text { matrix. } \\
\text { Narrow street areas, } \\
\text { underused in stage one, } \\
\text { become exposed to the } \\
\text { aspiration to maximize } \\
\text { the profit of individual } \\
\text { developers. The open } \\
\text { street frontages of } \\
\text { super-blocks (blocks } 61 \text {, } \\
63 \text {, and } 64 \text { ) are closed by } \\
\text { lines of five to eight-story } \\
\text { buildings. Floor area } \\
\text { ratio ranges from } \\
50-100 \% \text { (block } 64 \text { ). }\end{array}$ \\
\hline $\begin{array}{l}\text { Retreat from } \\
\text { community-oriented } \\
\text { planning initiatives }\end{array}$ & $\begin{array}{l}\text { Abandoning the idea of } \\
\text { community facilities. } \\
\text { Sports and cultural } \\
\text { centers of importance to } \\
\text { the district remain } \\
\text { unbuilt (block } 44 \text { ). The } \\
\text { priority becomes } \\
\text { consumerism: farmer's } \\
\text { market, department } \\
\text { store, and shopping mall } \\
\text { (block } 44 \text { ). }\end{array}$ & $\begin{array}{l}\text { Abandoning the idea of } \\
\text { local community } \\
\text { centers. Community } \\
\text { centers, garages, and } \\
\text { pedestrian underpasses } \\
\text { of super-block } \\
\text { importance remain } \\
\text { unbuilt (blocks } 61 \text { and } \\
\text { 63). The priority } \\
\text { becomes } \\
\text { commercialization: } \\
\text { shopping mall, petrol } \\
\text { stations, residential } \\
\text { buildings with shops on } \\
\text { the ground floor, and } \\
\text { auto repair shop are built } \\
\text { (blocks } 45,61,63 \text {, } \\
\text { and } 70 \text { ). }\end{array}$ & $\begin{array}{l}\text { Abandoning the idea of } \\
\text { the open block. } \\
\text { Priority becomes } \\
\text { land-to-building ratio. } \\
\text { Plots intended for } \\
\text { community centers are } \\
\text { re-zoned to permit } \\
\text { housing development; } \\
\text { the final result is the } \\
\text { construction of } \\
\text { residential buildings } \\
\text { with retail space on the } \\
\text { ground floors (blocks } 45, \\
61,63 \text {, and } 64 \text { ). }\end{array}$ \\
\hline
\end{tabular}


Table 2. Cont.

Destruction of
traditional
working-class
neighborhoods in order
to make way for
speculative
redevelopment

Distinction. New structures are distinct from neighboring blocks. They differ in the traditional working-class standard: more comfortable flats, lower buildings, and a more humane environment and public spaces (block 44).
Complementarity. The decrease of social and economic standards justify the appearance of informal structures (block 62), small rentable-scale retail facilities (blocks 45 and 70), and private recreational facilities (block 62); physically incompatible with the initial concept of the area, yet satisfying the needs of the residents.
Conflict. The new structures occupy privileged positions along the main street and are contextually different from existing residential structures regarding the urban form, social status, lifestyle, culture, and age. These new structures enclose the courtyards and confront the privileged parts of megastructures and privileged social groups of the previous social system: military servants and state officials (blocks 61-64).

\begin{tabular}{|c|c|c|c|}
\hline \multicolumn{4}{|l|}{ (B) } \\
\hline $\begin{array}{l}\text { MOMENTS OF } \\
\text { CREATION }\end{array}$ & STAGE ONE (Figure 1) & STAGE TWO (Figure 2) & $\begin{array}{l}\text { STAGE THREE } \\
\text { (Figure 3) }\end{array}$ \\
\hline $\begin{array}{l}\text { Creation of new } \\
\text { privatized spaces for } \\
\text { elite/corporate } \\
\text { consumption }\end{array}$ & $\begin{array}{l}\text { Large-scale unbuilt } \\
\text { plots. Most development } \\
\text { plots, constituting the } \\
\text { street frontage in the first } \\
\text { stage, range from } \\
10.7-16.7 \text { hectares in area } \\
\text { (blocks } 61-64 \text { ) and } \\
5.4-10.2 \text { hectares zoned } \\
\text { for public use divided } \\
\text { from residential blocks } \\
\text { by roads }(45,44, \text { and } 70) \text {. }\end{array}$ & $\begin{array}{l}\text { Frontage divided. Plot } \\
\text { subdivision is developed } \\
\text { without consideration of } \\
\text { the importance of the } \\
\text { corner sites, both from } \\
\text { architectural and market } \\
\text { logic (blocks } 45 \text { and } 70 \text { ). } \\
\text { Corner plots are equal in } \\
\text { size (up to one hectare). } \\
\text { The largest plot (two } \\
\text { hectares) is positioned } \\
\text { along the main axis of } \\
\text { the residential block, } \\
\text { emphasizing its central } \\
\text { entryway. On the } \\
\text { contrary, temporary } \\
\text { informal structures for } \\
\text { illicit trade are situated } \\
\text { on the corners (blocks } 45 \text {, } \\
62, \text { and } 70 \text { ). }\end{array}$ & $\begin{array}{l}\text { Fragmentation of the } \\
\text { matrix. } \\
\text { Planned access roads for } \\
\text { unbuilt community } \\
\text { facilities become streets } \\
\text { for housing } \\
\text { developments for the } \\
\text { new elite. Plot } \\
\text { subdivision into } \\
\text { fragments ranging from } \\
0.25-0.9 \text { ha, both in the } \\
\text { narrow street area and } \\
\text { inner sections of the } \\
\text { block. To service all of } \\
\text { the newly created plots, } \\
\text { the street matrix is either } \\
\text { modified and extended } \\
\text { for private consumption } \\
\text { (block } 63 \text { ) or } \\
\text { appropriated (block 45). }\end{array}$ \\
\hline $\begin{array}{l}\text { 'Rolling forward' of the } \\
\text { gentrification frontier } \\
\text { and the intensification } \\
\text { of socio-spatial } \\
\text { polarization }\end{array}$ & $\begin{array}{l}\text { Stratification by status. } \\
\text { Although differences in } \\
\text { status are already } \\
\text { present under socialism, } \\
\text { they are not apparent in } \\
\text { the spatial segregation of } \\
\text { housing before the } \\
\text { construction of new } \\
\text { structures (block } 44 \text { ). }\end{array}$ & $\begin{array}{l}\text { Polarization by status } \\
\text { and race. A section of } \\
\text { the street is referred to as } \\
\text { a 'Chinatown' (block 70), } \\
\text { indicating the differences } \\
\text { in race, status, economic } \\
\text { power, and character } \\
\text { from the rest of the } \\
\text { residential area of the } \\
\text { block. The street } \\
\text { frontage reveals both the } \\
\text { racial segregation and } \\
\text { declining economic } \\
\text { power of the residents. }\end{array}$ & $\begin{array}{l}\text { Polarization by status. } \\
\text { The diversity of urban } \\
\text { structures, real estate } \\
\text { prices, and prices of } \\
\text { services offered in the } \\
\text { narrow street area } \\
\text { suggest segregation by } \\
\text { status. }\end{array}$ \\
\hline
\end{tabular}




Construction of
large-scale
megaprojects intended
to attract corporate
investment and
reconfigure local
land-use patterns

Construction of megaprojects intended to attract corporate reconfigure local land-use pattern

\begin{abstract}
The idea of the open block is preserved. Building form, land-use, and pedestrian and vehicular routes are developed according to the principles of the open block pattern.
\end{abstract}

Fragmentation of open block to the narrow street area and rest of the block.

Amendments to planning documents deal only with the narrow street area separating it from the rest of the block, both as a morphological and planning unit.
Fragmentation of narrow street area. Insertion of one urban pattern into another. New urban complexes are constructed as singular morphological units within open-plan blocks. Emphasis is placed on market-driven construction on corner sites. This new pattern prioritizes direct vehicular access to new facilities (predominantly residential), resulting in a conflict between vehicular and pedestrian routes.

\section{Discussion and Conclusions}

Tracing neoliberal aspirations in the morphogenesis of Jurija Gagarina Street through a detailed analysis of its contextual framework, urban policies, and morphological transformation has revealed the causes and means of fragmentation of the morphology of the superblock (Figure 7). Fragmentation is the most perceivable through analysis of the character areas, which (in the first period) decreased from the initial 115 ha to 36 ha. After the break-up of Yugoslavia and collapse of the socialist system, this area was further reduced to $2 \mathrm{ha}$. In the period of democratic changes, the character area was brought to the scale of a single plot ranging from $0.2-0.4$ ha, a fragment only $0.17 \%$ of the initial character area. This physical fragmentation was followed by the reduction of the roles and responsibilities of planners and the reduction of the planning documents' scope regarding the scale.

Detailed analysis of the moments of creation and destruction provide an insight into the locally-specific manifestations of neoliberal mechanisms induced by urban policy changes (plan amendments on both the macro and micro levels). The study has revealed that the transition from collective to private land ownership in Serbia has caused four most distinguishable effects on the urban form in the modernist settlement:

A-Densification and creation of new privatized spaces of exclusive consumption

Amendments to the GMP and DUP jointly enabled the creation of new privatized spaces of elite/corporate consumption. First, the GMP enabled a higher built-up area ratio in the commercial streets included in the location under study. This amendment further implied a change in perception of unbuilt areas in the street frontage as sites for new construction, new uses, and higher built-up area ratio, as a DUP had never been fully implemented. It is worth mentioning that the most attractive sites were privatized and constructed only in the third period of morphogenesis, under new conditions and a higher built-up ratio (intended for housing with commercial activities). As an epilogue, new properties on the block corners exist as elite housing estates at present.

B-Intensification of socio-spatial polarization without necessarily producing gentrification

Changes in urban policies have gradually led to socio-spatial polarization, which is most clearly seen through the strengthening of the small-scale businesses and their primacy over the public interest. The conflict over collective resources is particularly evident, which dates back to the first period of morphogenesis-the final phase of socialist self-management. The favorable conditions for the development of small-scale businesses were further increased in the second period, through DUPs which enabled the development of small business premises within collective housing (which were subsequently privatized in the second phase). The third period of morphogenesis was dominated 
by construction based on private capital, perceivable through urban policies making numerous compromises with developers and a reduced investment in public spaces and shared resources. Consequently, the profits of developers became the sole principle for area development.

C-Reconfiguration of local land-use patterns

The specific configuration of the land-use pattern in the subject area was induced by the insertion of a traditional city block pattern to open block one. The uniqueness lies in the occupation order of the street frontage, which went from the plots located in the central area of the street frontage (in the second period) to the occupation of the corners (in the third period). Intensification of the occupancy of plots at the edges was supported by specific social housing policies introduced at the beginning of the third period and changes in the built-up area ratios for the open block, introduced through several amendments to the GMP. The central plots of the street frontage were planned for social housing, in order to leave plots on the corners to be sold on the market (as they allowed a higher built-up area ratio).

D-Withdrawal from community-oriented planning initiatives toward efficient planning services

A gradual departure from traditional community-oriented planning, specifically in the New Belgrade area, can be traced through the analysis of land-use changes in the DUPs. In the first period, the idea of community facilities was abandoned, while in the second period the idea of local community centers was abandoned as well. As a result, housing was the dominant land-use, with no additional facilities. In the third period, the idea of the open block was completely abandoned, followed by the usurpation of public spaces intended for the community.

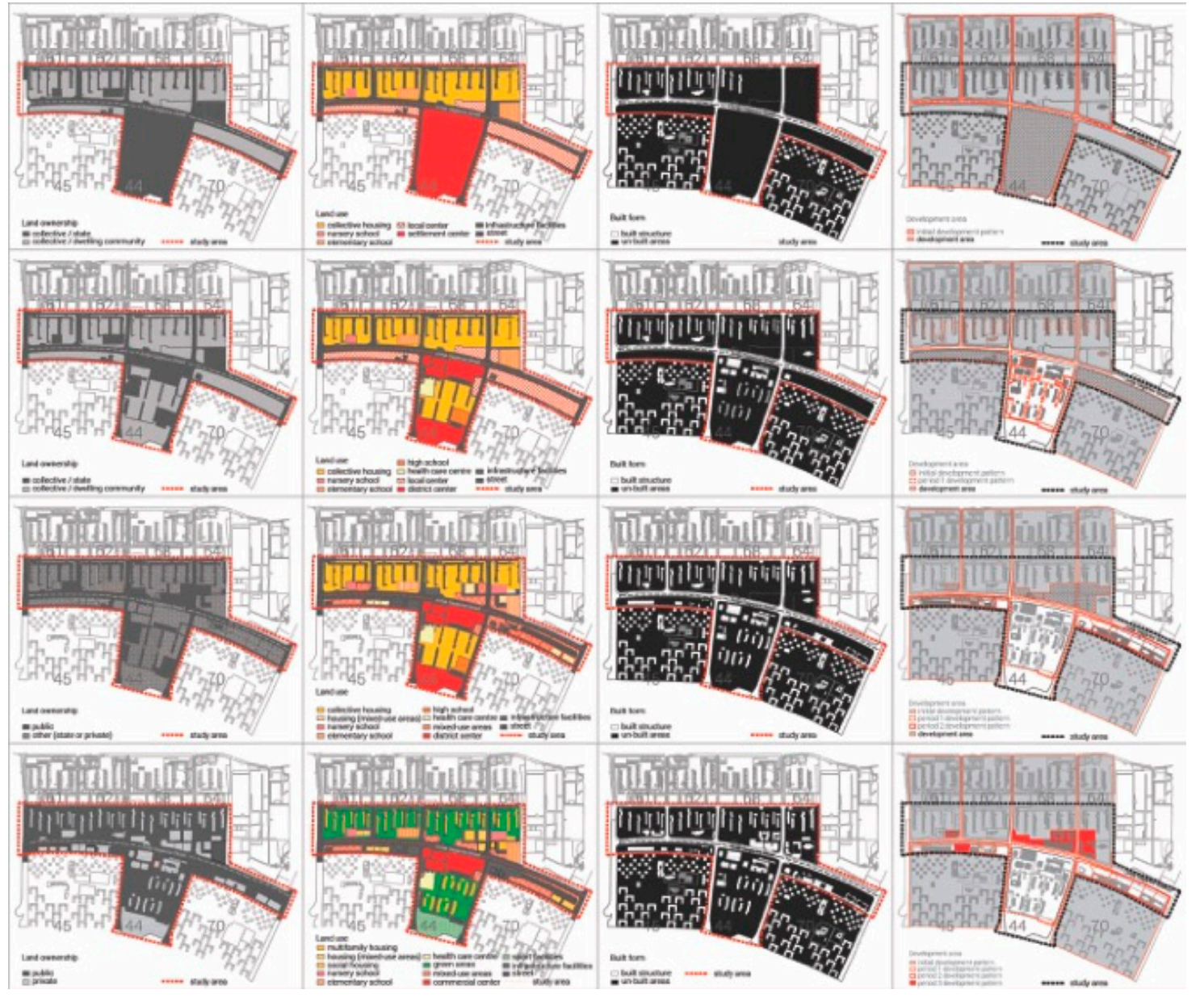

Figure 7. Transition of collective land: causes and means of fragmentation of the morphology of the superblock (source: authors). 
As it cannot be said that neoliberal capitalism has been fully established in Serbia-since the institutions of such a system have not yet been established [53,54]—one can only speak about neoliberal ambitions, aspirations, and values that have influenced the dominant patterns of city development. This research reveals that these aspirations are not just of recent influence, but have been present in Serbia since the socialist system of self-government; they can be identified in all three analyzed periods. What is particularly important to emphasize is the role of urban policies in legitimizing neoliberal values.

Morphological studies usually deal with the change of urban form, identifying the time when the change occurred and the extent of the transformation. This research differs from these usual studies, as the periods were derived based on an analysis of the institutional framework, while the change in urban form was discerned by an analysis of changes in land ownership and land-use. On the other hand, observing the studies predominantly concerned with the analysis of the institutional framework and changes in the planning system, this research stands out as it strives to identify, monitor, and present the changes using spatial parameters found through a particular case study.

Future research could build on the findings in this paper, considering and comparing more directly the implications of the neoliberal aspirations on specific sites in both post-socialist and global capitalist countries.

Author Contributions: Conceptualization, M.P.M.; Formal analysis, M.P.M.; Investigation, M.P.M. and A.D.; Methodology, M.P.M. and M.M.; Resources, M.M. and A.D.; Supervision, M.M.; Visualization, M.P.M.; Writing-original draft, M.P.M., M.M. and A.D.; Writing—Review \& Editing, M.P.M. and A.D.; Visualization, M.P.M.

Funding: This research received no external funding.

Conflicts of Interest: The authors declare no conflict of interest.

\section{References}

1. Brenner, N.; Theodore, N. Cities and the Geographies of Actually Existing Neoliberalism. Antipode 2002, 34, 349-379. [CrossRef]

2. Tominc, P.; Rebernik, M. Growth aspirations and cultural support for entrepreneurship: A comparison of post-socialist countries. Small Bus. Econ. 2007, 28, 239-255. [CrossRef]

3. Voiculescu, S.; Crețan, R.; Satmari, A.; Ianăş, A.-N. The Romanian Post-Socialist City. In Urban. Renewal and Gentrification; Editura Universitatii de Vest: Timisoara, Romania, 2009.

4. Andrusz, G.; Harloe, M.; Szelenyi, I. Cities after Socialism: Urban and Regional Change and Conflict in Post-Socialist Societies; Wiley-Blackwell: Oxford Cambridge, UK, 1996.

5. Gavrilidis, A.A.; Gradinaru, S.R.; Ioja, C.; Carstea, E.M. Land use and land cover dynamics in the periurban area of an industrialized East-European city. An overview of the last 100 years. Carpathian J. Earth Environ. Sci. 2015, 10, 29-38.

6. Soaita, A.M.; Dewilde, C. A Critical-Realist View of Housing Quality within the Post-Communist EU States: Progressing towards a Middle-Range Explanation. Hous. Theory Soc. 2017, 36, 44-75. [CrossRef]

7. Whitehand, J. British urban morphology: The Conzenion tradition. Urban Morphol. 2017, 5, 103-109.

8. Boland, P.; Bronte, J.; Muir, J. On the waterfront: Neoliberal urbanism and the politics of public benefit. Cities 2017, 61, 117-127. [CrossRef]

9. Sager, T. Neo-liberal urban planning policies: A literature survey 1990-2010. Prog. Plan. 2011, 76, 147-199. [CrossRef]

10. Goldman, M. Speculative urbanism and the making of the next world city. Int. J. Urban. Reg. Res. 2015, 35, 555-581. [CrossRef]

11. Kropf, K. Urbanism, politics and language: The roles of urban morphology. Urban. Morphol. 2011, 15, 157-160.

12. McGlynn, S. Reviewing the rhetoric. In Making Better Places: Urban Design Now; Architectural Press: Oxford, UK, 1993; pp. 3-9.

13. Peck, J.; Theodore, N.; Brenner, N. Neoliberal urbanism: Models, moments, mutations. Sais Rev. Int. Aff. 2009, 29, 49-66. [CrossRef] 
14. Carmona, M. Design Coding and the Creative, Market and Regulatory Tyrannies of Practice. Urban. Stud. 2009, 46, 2643-2667. [CrossRef]

15. Stanilov, K. Urban planning and the challenges of post-socialist transformation. In The Post-Socialist City: Urban Form and Space Transformations in Central And Eastern Europe After Socialism; Stanilov, K., Ed.; Springer: Dodrecht, The Netherlands, 2007; pp. 413-425.

16. Hirt, S. Whatever happened to the (post)socialist city? Cities 2013, 32, 529-538. [CrossRef]

17. Tsenkova, S. Beyond transitions: Understanding urban change in post-socialist cities. In The Urban Mosaic of Post-Socialist Europe: Space, Institutions and Policy; Tsenkova, S., Nedović-Budić, Z., Eds.; Physica-Verlag: Heilderberg, Germany, 2006; pp. 21-50.

18. Tosics, I. Spatial restructuring in post-socialist Budapest. In The Urban Mosaic of Post-Socialist Europe: Space, Institutions and Policy; Nedović-Budić, Z., Tsenkova, S., Marcuse, P., Eds.; PhysicaVerlag: New York, NY, USA, 2006; pp. 131-150.

19. Zeković, S.; Vujošević, M. Construction land and urban development policy in Serbia: Impact of key contextual factors. In A Support to Urban Development Process; Bolay, I.J., Maričić, T., Zeković, S., Eds.; EPFL \& IAUS: Belgrade, Serbia, 2018; pp. 29-50.

20. Hartmann, T.; Needham, B. (Eds.) Planning by Law and Property Rights Reconsidered; Ashgate: Farnham, UK, 2012.

21. Zeković, S. Planiranje urbanog zemljišta u Srbiji [Urban land planning in Serbia]. Arhit. Urban 2002, 9, 11-17.

22. Maruna, M.; Crnčević, T.; Milojević, M.P. The Institutional Structure of Land Use Planning for Urban Forest Protection in the Post-Socialist Transition Environment: Serbian Experiences. Forests 2019, 10, 560. [CrossRef]

23. Vujosevic, M.; Nedovic-Budic, Z. Planning and societal context-The case of Belgrade. In Urban Mosaic of Post-Socialist Europe: Space, Institutions and Policy; Tsenkova, S., Nedovic-Budic, Z., Eds.; Springer: Heidelberg, Germany, 2006; pp. 275-293.

24. Petrović, M. Transformacija Gradova: Ka Depolitizaciji Urbanog Pitanja [City Transformations: Towards Depolitization of an Urban. Question]; ISI FF: Beograd, Serbia, 2009.

25. Perić, A.; Maruna, M. Predstavnici društvene akcije u procesu regeneracije priobalja - slučaj braunfild lokacije Luka Beograd. Sociol. Prost. 2012, 50, 61-88.

26. Zeković, S.; Vujošević, M.; Maričić, T. Spatial regularization, planning instruments and urban land market in a post-socialist society: The case of Belgrade. Habitat Int. 2015, 48, 65-78. [CrossRef]

27. Miljković, J.Ž. Urban Land Use regulation in Serbia: An analysis of its effects on property rights. In A Support to Urban Development Process; Bolay, J., Maričić, T., Zeković, S., Eds.; EPFL \& IAUS: Belgrade, Serbia, 2018; pp. 129-147.

28. Stupar, A. Cold War vs architectural exchangde: Belgrade beyond the confines. Urban. Hist. 2015, 42, 622-645. [CrossRef]

29. While, A. Modernism vs urban renaissance: Negotiating post-war heritage in English city centres. Urban. Stud. 2006, 43, 2399-2419. [CrossRef]

30. Aelbrecht, P.S. The complex regeneration of post-war modernism: London's Southbank Centre's Masterplan. Urban Des. Int. 2017, 22, 331-348. [CrossRef]

31. Talen, E. Design by the Rules. The Historical Underpinnings of Form-Based Codes. J. Am. Plan. Associ. 2009, 75, 144-160. [CrossRef]

32. van den Dool, L.; Hendriks, F.; Gianoli, A.; Schaap, L. The Quest for Good Urban. Governance- Theoretical Reflections and International Practices; Springer: Wiesbaden, Germany, 2015.

33. Alawadi, K.; Khanal, A.; Almulla, A. Land, urban form, and politics: A study on Dubai's housing landscape and rental affordability. Cities 2018, 81, 115-130. [CrossRef]

34. OECD (Organisation for Economic Co-operation and Development). Land-Use Planning Systems in the OECD: Country Fact. Sheets; OECD Publishing: Paris, France, 2017.

35. Birkhamshaw, A.J.; Whitehand, J.W. Conzenian urban morphology and the character areas of planners and residents. Urban Des. Int. 2012, 17, 4-17. [CrossRef]

36. Nedović-Budić, Z.; Cavrić, B. Waves of planning: A framework for studying the evolution of planning systems and empirical insights from Serbia and Montenegro. Plan. Perspect. 2006, 21, 393-425. [CrossRef]

37. Pajović, D. Pregled Urbanističkog Zakonodavstva Srbije [Overview of Urban. Legislation]; Udruženje urbanista: Novi Sad, Serbia, 2005. 
38. Vujović, S. Akteri urbanih promena u Srbiji [Actors of Urban Changes in Serbia]. In Društvena Transformacija i Strategije Društvenih Grupa: Svakodnevica Srbije na Početku Tré́eg Milenijuma [Societal Transformation and Strategies of the Third Millennium]; Milić, A., Ed.; Institut za sociološka istraživanja Filozofskog fakulteta u Beogradu: Beograd, Serbia, 2004; pp. 151-193.

39. Vujošević, M.; Zeković, S.; Maričić, T. Post-socialist transition in Serbia and its unsustainable path. Eur. Plan. Stud. 2012, 20, 1707-1727. [CrossRef]

40. Vujošević, M. Collapse of Strategic Thinking, Research and Governance in Serbia and Possible Role of the Spatial Plan of the Republic of Serbia (2010) in its Renewal. Spatium 2010, 23, 22-29. [CrossRef]

41. Maruna, M.; Čolić, R.; Rodić, D.M. A New Regulatory Framework as both an Incentive and Constraint to Urban Governance in Serbia. In A Support to Urban Development Process; Bolay, J., Maričić, T., Zeković, S., Eds.; EPFL \& IAUS: Belgrade, Serbia, 2018; pp. 80-108.

42. GMP. Generalni Urbanistički Plan. Beograda do 2000 [General Master Plan. for Belgrade to 2000]; Urbanistički zavod: Beograda, Serbia, 1972.

43. GMP. Amendments, Izmene Generalnog Urbanističkog Plana Beograda [Amendments to the General Master Plan. for Belgrade]; Sl.list Beograda 75/87/92; Grad Beograd: Belgrade, Serbia, 1975.

44. DUP. Detaljan Urbanistički Plan. sa Urbanističkim Projektom za Blok 44 u Novom Beogradu; Urbanistički Zavod Beograda: Beograd, Serbia, 1984.

45. DUP. Amendments, Izmena Detaljnog Urbanističkog Plana Bloka 44 u Novom Beogradu; Zavod za Urbanizam Beograda: Beograd, Serbia, 1985.

46. DUP. Detaljan Urbanistički Plan Blokova 45 i 70 na Novom Beogradu [Detailed Urban Plans for the Parts of Blocks 45 and 70 in New Belgrade]; Sl. list Beograda br. 9/66; Grad Beograd: Belgrade, Serbia, 1966.

47. DUP. Amendments, Izmene i Dopune Detaljnog Urbanističkog Plana Stambenog Naselja Bežanija (blokovi 61, 62, 63 i Delovi Blokova 64, 60, 57 i 57a) u Novom Beogradu [Amendments to the DUP for the Area of Bežanija (Blocks 61, 62, and 63; Parts of Blocks 62, 60, 57, and 57a); Sl. List Grada Beograda, br. 3/91; Grad Beograd: Belgrade, Serbia, 1992.

48. DUP. Amendments, Izmene i Dopune Detaljnog Urbanističkog Plana Blokova 45 i 70 na Novom Beogradu [Amendments to the Detailed Urban Plan for Blocks 45 and 70 in New Belgrade]; Sl.list Beograda br. 10/75, 14/75, 4/87, 5/87, 6/92; Grad Beograd: Belgrade, Serbia, 1992.

49. GMP. Generalni Urbanistički Plan Beograda 2021 [General Master Plan for Belgrade to 2021]; Sl.list Beograda br. 27/03; Grad Beograd: Belgrade, Serbia, 2003.

50. GMP. Amendments, Izmene Generalnog Urbanističkog Plana Beograda [Amendments to the General Master Plan for Belgrade]; Sl.list Beograda br. 63/09; Sl.list Beograda br.: Belgrade, Serbia, 2009.

51. PGR. Plan of General Regulation; Sl. lista grada Beograda br.63/16; Grad Beograd: Belgrade, Serbia, 2016.

52. Djokić, V.; Trajković, J.R.; Krstić, V. An Environmental Critique: Impact of Socialist Ideology on the Ecological and Cultural Sensitivity of Belgrade's Large-Scale Residential Settlements. Sustainability 2016, 8, 914.

53. Bajec, N.L. Rational or collaborative model of urban planning in Serbia: Institutional limitations. Serb. Archit. J. 2009, 1, 81-106.

54. Nedović-Budić, Z.; Djordjević, D.; Dabović, T. The Mornings after Serbian Spatial Planning Legislation in Context. Eur. Plan. Stud. 2011, 19, 429-455. [CrossRef]

(C) 2019 by the authors. Licensee MDPI, Basel, Switzerland. This article is an open access article distributed under the terms and conditions of the Creative Commons Attribution (CC BY) license (http://creativecommons.org/licenses/by/4.0/). 